\title{
Self-assessment Based on Language Learning Outcomes: A Study with First Year Engineering Students
}

\author{
Pilar Durán Escribano and Joana Pierce McMahon \\ Polytechnic University of Madrid
}

\begin{abstract}
As the Bologna Process moves forward, changes in European systems of higher education are expected. The introduction of the ECTS focussing on the students' achievements described in terms of the learning outcomes and competences acquired is one of the innovations. This process, encouraged by Universidad Politécnica de Madrid, signifies a change in teaching focus, from an input model to an output one, which promotes self-assessment in a flexible curriculum, in this case adapted to student's language profile. To illustrate this new approach in language learning, a pilot experience with Technical English mining engineering students is discussed, with special attention to learner reflection and self-assessment practices. Students' progress in self-assessment, based on the introduction of learning outcomes in specific language courses, is analysed to conclude that personal engagement and clear purpose -specified in terms of learning outcomes- seem to have become relevant components to student's self-assessment practice.
\end{abstract}

\section{Introduction: changing the focus to meet curriculum reform}

Higher education in Spain has seen some substantial changes in accordance with the adaptation to the European Higher Education Area (EHEA). On January 2005, following the Bologna process, the Spanish Ministry of Education regulated the restructuring of degrees, establishing the new European Credit Transfer System (ECTS) by the year 2010. The ECTS is a student-centred system focusing on the student workload required to achieve the 
objectives of a programme, specified as learning outcomes and competences to be acquired.

For the past decades, Spanish engineering degrees have been organised under a two tier system: technical engineers (3-4 years) and engineers (5-6 years) with the traditional credit system based on teaching hours primarily measuring activities that require the presence of the teacher (lectures, problem sessions, seminars, lab activities, etc.). Assessment has been mostly summative, with students demonstrating that they have learned the required knowledge about the subject, and reached an adequate level. Knowledge and learning have been traditionally viewed as measurable and clearly defined products (Huba and Freed, 2000). Thus, the courses were described in terms of what would be covered, emphasising the length of a programme, its access requirements, and number of teacher contact hours.

Referring to a change in teaching focus towards an output model, Sfard (1998) argued that the traditional product oriented acquisition metaphor must be complemented by a 'process oriented participation metaphor', thus emphasising the important dynamic tension between structure and process. The teacher must provide structure, but only to the extent that it helps the student through the learning process (Brunner, 1996). Teaching, learning and assessment are inseparable practices, where students are considered active participants in the development of assessment procedures in which both the task processes and products should be evaluated. This implies a change in teaching focus, and, consequently, the assessment results need to be reported as a qualitative profile rather than as a single score (Birenbaum, 1996). Proponents of assessment for learning agree that classroom assessment has a crucial role to play in effective teaching and learning (Gardner, 2006); and, furthermore, that selfassessment is essential to learning 'because students can only achieve a learning goal if they understand that goal and can assess what they need to do to reach it' (Black and Williams 2006:15).

Within this context, the new ECTS means that universities are introducing competences and learning outcomes into their curricula to foster self-guided learning and assessment. This should cause a change of focus in higher education from content-teacher based education to a student-centred learning approach, which implies that students should be actively involved in the planning, management, and assessment of their own learning. Little supports that the most valuable way to measure learning is to incorporate self-assessment into the very learning process, ensuring that students are provided with clear assessment criteria and sufficient information on the quality of their learning outcomes (Little, 2005 and 2007).

We believe that the introduction of specific language learning outcomes that articulate learning goals into specific language programmes and of self-assessment practices can promote a paradigm shift in engineering education. In our area, the teaching of language communication skills, we have been working on introducing competences, learning outcomes, and self-assessment practices into our English language courses, mostly dealing with technical, academic and professional language usage.

\section{Self-reflection strategies and learning outcomes}

Self-reflection strategies and learning outcomes are an important source for language learning 
improvement. If our students become more reflective about their learning needs, their personal growth as well as their language communication competences will be enhanced. Self-reflection offers the opportunity for them to connect language learning goals with their personal life, thus fostering more positive and long-lasting results as they assume the responsibility for their own learning process (Light and Cox, 2001; Kollias and Kikis, 2005). This is why the use of self-reflection by the students has been emphasised by most recent learning theories (Meichenbaum and Biemiller, 1998; Robinson, 2002; Skehan, 1998). We think that we should take advantage of the motivational inner force of having students engaged reflectively in setting and following their own language learning goals (Little, 2005; Van Lier, 2007). In this sense, learning outcomes stating competence levels can be an efficient tool for students self-reflection practices (Durán and Pierce, 2007a; Pierce and Robisco, 2010).

However, learning outcomes and competences is a complex area. Competence can broadly refer to proven ability, proficiency, capability, skills and understanding. It can represent a combination of attributes and be used to describe the extent to which a person is capable of performing them. A competence or set of competences means that a person can demonstrate a certain capacity and perform a task in a way that allows evaluation of the level of achievement.

Learning outcomes have been described as a basic educational building block, at the core of higher education quality enhancement, related to concrete competences. Outcomes are concerned with the learner's achievements rather than the teacher's intentions. Their use makes the objectives of learning programmes clearer and more easily understood for students. They have a direct relationship to levels and level indicators, as it is emphasised in the guidelines for the application of the ECTS. "Learning Outcomes describe what a learner is expected to know, understand and be able to do after successful completion of a process of learning. They relate to level descriptors in national and European qualifications frameworks" (ECTS Users' Guide, 2009:11). In the following section we shall describe how our language learning outcomes were developed and scaled to the European framework of reference CEFRL.

\section{Language learning outcomes and competences specific for EST students}

Learning outcomes and competences, as defined in European Higher Education contexts, can be used interchangeably in that both terms refer to what the learner will know, understand and be able to do, that is, the proven ability to use knowledge and other personal skills for a purpose. In order to prepare for the EHEA renovation, our research group DISCYT ${ }^{1}$, has developed a bank of language competence descriptors, based on a thorough needs analysis of communication competences for English for science and technology (EST) students (Durán et al., 2009). This bank of competence descriptors can be flexibly applied in different language programmes at different engineering schools, and aims to match academic literacy requirements specific of engineering higher education students. It can serve two major pedagogical purposes. Primarily, it serves as a detailed list of language competences to be 
used for self-directed learning and self-assessment. The students can identify and set goals to assess their learning progressively, inside and outside the educational framework (Little and Perclová, 2005). Secondly, learning outcomes can be a pedagogical resource for teachers to determine the key purposes of the course if they are properly selected and flexibly applied (Durán and Pierce, 2007b).

\subsection{Features of the EST language competence descriptors as 'can do statements'}

Before the actual writing of our EST specific language competence descriptors, existing descriptors, within the area of the European Language Portfolio (ELP) experiences, were consulted (Foster Vosicki, 2002; Lenz and Schneider 2004). A good language competence descriptor should be positive, definite, clear, brief and independent in describing concrete outcomes or degrees of skill. That is, it should be formulated using positive descriptions not only of what the learners can do, but also of how well they can do it. Finally, the descriptors should be independent of each other and be answerable with a clear 'I can do this' or 'I can't do this' (Lenz and Schneider, 2004: 13). Although, these ELP guidelines and self-assessment checklists served as a starting point and good model for writing new descriptors, they did not contemplate the specific needs of our engineering students (Pierce and Ubeda, 2006); thus, specific check lists had to be further developed.

The range of effective communication competences required of engineering students includes fundamental academic skills, such as reading specific material, writing and speaking in an adequate register, mastering specific terminology and the strategies required to consult sources and solve technical problems, as well as working with oral and written texts through the processes of note-taking and translation (Durán and Cuadrado, 2007). Special attention was given to writing skills, as engineering is one field where proficiency in written communication is valued (Johns, 1997). Consequently, our Academic and Professional bank of language descriptors, integrated within the ACPEL Portfolio (Durán et al., 2009), encourages a variety of written and spoken genres, as well as attention to the creative processes (planning, outlining, writing, presenting) and production strategies. This includes working with feedback, revision and editing, as well (Pierce and Durán, 2008).

Following European directives, in order for competence descriptors to be the basis for methodological course design and student self-assessment practice, they need to be scaled to the Common European Framework of Reference for Languages (CEFR) levels (Council of Europe 2001). Thus, the CEFR was chosen as our external reference, as it provides a practical tool for setting clear standards to be attained at successive learning stages and for evaluating outcomes in an internationally comparable manner. Language competence is divided into 6 levels clustering into 3 bands: A1-A2 (basic user), B1-B2 (independent user), and C1-C2 (proficient user); these should be used as a flexible goal setting reference point rather than as a fixed classification grid for examinations level and students' language assessment (Schneider and Lenz, 2000).

The next step was to test the new outcome descriptors for clarity with our respective students; this was carried out by June 2006 (Durán and Cuadrado, 2007: 105-122; Pierce and Robisco, 2010). It is important to note here that since one of the purposes of the learning 
outcomes bank is its use in student self-assessment, it is paramount that the students understand the description of the outcomes. Unclear statements of learning outcomes do not serve the purpose of motivating the self-directed language learning process and selfassessment inherent; therefore, all those descriptors that were noted as unclear were rewritten. The final has been a bank of 355 descriptors, ranging from A1 to C2 CEFR levels, grouped under seven categories: listening (46), reading (51), spoken interaction (34), spoken production (60), writing (93), working with texts (43) and communicative language competence (28), open to further development (Durán et al 2009).

In the next sections we shall report on a study carried out with first year technical mining engineering students enrolled in their compulsory Technical English I course, in the second semester on 2007-08 academic year.

\section{Implementing self-assessment of specific language learning outcomes}

This study was designed to enhance our understanding of engineering students' capacity and reliability to assess their performance of the language tasks necessary to achieve a desired outcome previously selected for the course. Our aim was to observe and describe students' performance in self-assessment, by studying the relationship between results of external diagnostic tests and their self-assessment practices.

\subsection{Training the students}

As we said above, learner-centred approaches in L2 learning seek the development of learner autonomy, by assigning a central role to self-assessment. This process is an essential practice in order to train students to take decisions concerning their learning goals. However, first year students do not become self-directed learners instantaneously; rather they need opportunities as well as clear directions and careful planning in many instances (Bary and Rees, 2006; Inbar-Lourie, 2008). According to Boixareu, Dulin and De Santiago (2000: 67), getting students to make responsible decisions about their learning goals, both through independent and guided work, depends on two factors: first, on the student's maturity and, secondly, on a novel approach on the teachers' part to curriculum development. This includes methodological and assessment practices coherent with the new learning principles, a rationale that the ECTS firmly supports (Kavaliauskiené, et al., 2007; Yang, 2003).

Therefore, our first year students were given a brief explanation of the research project and were invited to participate voluntarily. To introduce our students into the practice of selfassessment, we discussed with them the explicit learning goals of the course, and the explicit assessment criteria to help them to decide whether they had attained the desired learning goals. We also provided them with detailed feedback by carrying out five class exercises. These were checked, marked and discussed with them during lecture hours. Five independent tasks were also carried out at home, which were also corrected and returned to the student authors. 


\subsection{Students' language proficiency level}

As students enter the university with varying levels of attainment, it was necessary to determine the students' English entry level before selecting the specific learning outcomes for the semester. We considered that this performance had to be taken into account when planning an EST course tailored to the students' needs and that the students had to be aware of the initial language level of their course objectives so they could realistically guide their learning process.

To do this, we administered the Oxford Placement Test for written language use, and the DIALANG Test for listening comprehension ability to our respective students enrolled in the course. Both these tests besides being reliable and easily administered are explicitly based upon the levels ofCEFR. Out of the 69 students enrolled, placed into two approximately equal groups by alphabetical order, a total of 52 sat both tests (figure 1), and 48 students also completed the self evaluation checklists.

The Oxford Placement Test is a test of English language proficiency that assesses reading ability and vocabulary and grammar use, in a multiple-choice format easy to administer. It is addressed to secondary age and above learners. It is designed to help teachers and learners to decide upon the student's level, although it is not meant to be an absolute indicator of the student's ability as it does not include other forms of assessment such as listening comprehension, speaking and writing. We have found the Oxford Placement Test a useful and reliable tool for placement purposes mapped to the six CEFR levels.

DIALANG has been a large and complex project funded by the European Union, which has produced a computer based battery of tests. Alderson (2005: 29) describes it thus: "DIALANG is an on-line learner-centred diagnostic language testing system that contains tests of five language skills: reading, listening, writing, vocabulary and grammar", at each of the six CEFR levels. For practical reasons we have only used the DIALANG listening test. This test assesses listening comprehension by measuring the students ability to understand/identify the main idea(s), main information or main purpose of a piece of spoken discourse, to listen intensively for specific details or specific information, to make inferences on the basis of what was heard, and to be able to use context to inform the approximate meaning of an unfamiliar word (Alderson 2005:142).

While a diagnostic test is used for the purpose of discovering a learner's language strengths and weaknesses, and provides results that may be used in making decisions on future learning or teaching, a placement test is meant to be administered to place students at a level appropriate to their degree of knowledge. But both diagnostic and placement language tests are designed to identify what a learner knows, understands and is able to communicate in order to decide on further teaching or learning. Student results from the Oxford Placement and DIALANG tests are shown in figure1. 


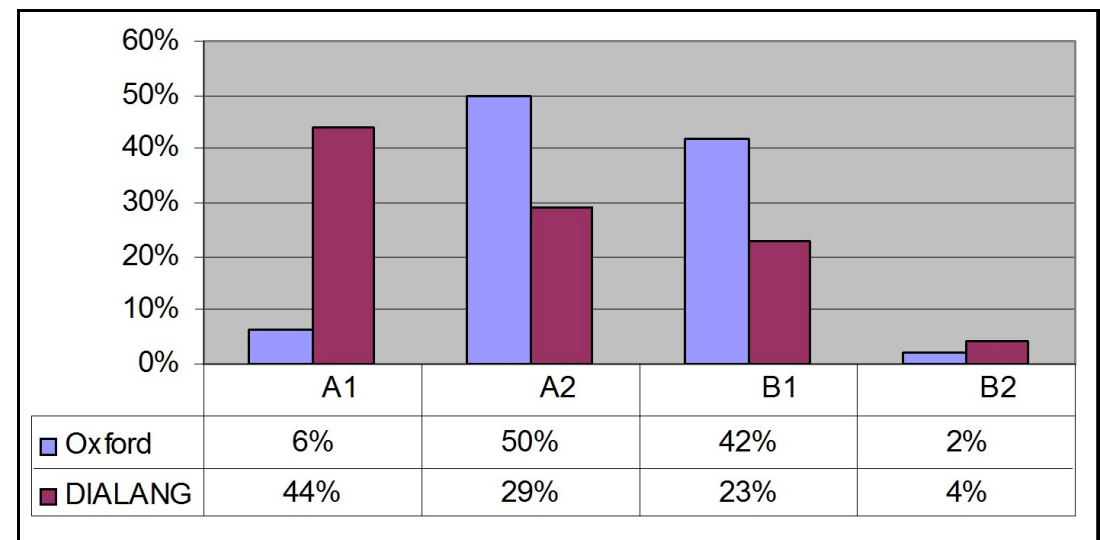

Figure 1. Results of Oxford Placement Test Test and DIALANG listening test.

The majority of the students fell between A2 and B1 levels on the Oxford Placement Test (92\%), while the majority fell between A1 and A2 on the DIALANG. Result percentages of both tests are arranged in a gradually decreasing order: from A2 to B2 in the Oxford Placement Test (excluding 6\% A1 students), and from A1 to B2 in the DIALANG. We believe a few reasons can account for the considerable gap between results in these two tests. First, perhaps the facilities were not optimum for the taking of DIALANG listening test. The test was taken in group in our Language Laboratory and perhaps the students were more distracted than if they took it on their own. Another reason is that our students may be less accustomed to the pacing of native oral input. Also, Spanish technical engineering students, in general, seem to perform better when working in English with written language than with spoken language, as we had found out in a previous study with 301 students enrolled in different Schools of Universidad Politécnica de Madrid (Durán and Pierce, 2007a). As can be seen in Figure 1, 50\% of the students fall in the A2 level on the Oxford Placement Test, the largest category, whose profile according to the CEFR includes understanding sentences related to areas of most immediate relevance, communicating in simple and routine tasks, and describing in simple terms aspects of their background. The following category was the B1 level with $42 \%$ of the students tested falling into this level. Their profile, according to the Council of Europe (2001), includes the understanding of main points of clear standard language on familiar matters, the production of simple connected texts on familiar topics, and giving explanations for opinions and plans. These two levels account for $92 \%$ of the students in the study.

Categories A1, B2, represent very low student percentages. Results showed that the majority of our first year technical mining students were referenced at CEFR A2 and B1, to move on to the next levels B1 and B2, respectively; very few reach $\mathrm{C} 1$ level of proficiency after a 60-hour course. Therefore, the main goal levels of our Technical English I class learning outcome descriptors were: Independent User B1 and B2, which correspond to threshold and vantage levels, and Proficient User C1, which corresponds to 'effective operational proficiency'. Students were not informed of their results of the tests at this point 
so as not to influence their self-assessment results; they were told their CEFR language level at the end of the course, together with their self-assessment results.

\subsection{The learning outcomes checklists adapted to Technical English students}

The next step for self-assessment was to determine learning outcomes adapted both to their compulsory 60-hour Technical English course objectives and their language proficiency level. Along the first two weeks of the semester we chose and discussed with our students the language competences and outcomes we were going to fix as goals for the course, within the listening comprehension, reading and writing skills. Spoken production was not considered for the study because of the difficulties entailed in its assessment and the large number of students in class. Therefore, we selected 16 out of 46 listening descriptors, 25 out of 51 reading descriptors, and 28 out of 93 writing descriptors, from the lists of our newly developed bank of 355 communicative competence descriptors (Durán et al, 2009). The three lists contained explicit learning outcomes as well as the description of the strategies related to each skill, worded as 'can do' statements. Within the writing list, besides, we included descriptors for overall written production, description of processes and mechanisms, reports, instructions, the cover letter and the $\mathrm{CV}$.

\subsection{Criteria for self-assessment}

In a regular classroom hour, students were asked to read the lists of learning outcomes, mapped to CEFR levels, and to identify them with the course objectives and the corresponding learning tasks. Then, they were told to mark only one of the three empty boxes placed on the right of each learning outcome; these boxes were: Column 1 'I can do this'; Column 2 'I am working on this but haven't reached it yet' (either in class or personally), and Column 3 'This is not my objective at the moment'. The students would read the can do statements (a sample is provided as an appendix), and were required to assess themselves for that competence. If a student considered that he/she was capable of doing what the descriptor said, he/she would mark the first column. If the student assessed himself as in the processes of acquiring the competence described, he/she would mark column two. Column three would then be marked by students who considered that the learning outcome or competence described was not a priority for them at that moment.

When completing the self-assessment checklists, participants were also encouraged to bear in mind the feedback received from the five class exercises checked and discussed with them, as well as their independent tasks carried at home, previously mentioned. Students were aware that their final mark was not only determined by the single exercises but also by the considerable degree of further learning involved in carrying out exercises and correcting them; continuous evaluation values progress and final outcomes above all. Similarly, they would have to take into account their progress made when practicing self-assessment and value their learning outcomes at the end of the course. Consequently, the checklists were gathered and analysed in May, after 50 hours of class, approximately. 


\subsection{Student self-assessment results}

To calculate the students' self-assessment level, the number of learning outcomes marked 'reached' in column 1 was totalled. Cut-off percentages of 'can do statements' were set for each level (table 1), allowing us to assign a self-assessment CERF level for each student. The third column in the table represents the percentage of students falling into each level according to our calculations. That is, if a student marked $95 \%-100 \%$ of the total can do statements as reached, including $\mathrm{C} 1$ statements, a self-assessment level of $\mathrm{C} 1$ was assigned to the students. Along the same lines, if a student marked $80-95 \%$ of the can do statements as reached, including B2 statements, he or she was assigned the B2 level and so on. Hence each student obtained a result from Oxford Placement Test and the result of the analysis for self-assessment of the can do statements.

\begin{tabular}{|l|l|l|}
\hline \multicolumn{1}{|c|}{ CEFR level } & cut-off \% reached & \multicolumn{2}{c|}{ Students \% } \\
\hline C1 & $95 \%-00 \%$ & $3 \%$ \\
\hline B2 & $80-95 \%$ & $16 \%$ \\
\hline B1 & $70-80 \%$ & $29 \%$ \\
\hline A2 & $40-70 \%$ & $38 \%$ \\
\hline A1 & $0-40 \%$ & $15 \%$ \\
\hline
\end{tabular}

Table 1. Cut-off percentage level reached for self-assessment calculations.

The self-assessment results for the DIALANG listening test are automatically calculated by the program itself, based on the answers of 18 'can do statements' about their ability in the skill of listening. Examples of such statements are: B1 "I can understand enough to manage simple routine exchanges without too much effort", A2 "I can follow clear speech in everyday conversation, though in a real- life situation, I will sometimes have to ask for repetition of particular words and phrases". Self-assessment in DIALANG is calculated by scores based on the Item Response Theory analyses which take into account the logit value of each of the student's statements. For a more thorough explanation of the calculation of self-assessment scores see Alderson (2005: 105). The DIALANG gives other feedback besides the level achieved and the self-assessment level. It gives the score on the vocabulary placement test describing the activities at that level and areas where the student may have problems. It also provides feedback on the correct and incorrect answers on the listening test according to their ability for overall understanding, listening for detail and making inferences. It adds comments on the effectiveness of the student self-assessment comparing it to the result of the DIALANG.

\section{Self-assessment analysis and conclusions}

\subsection{Reading and writing skills}

Once the self-assessment level on learning outcomes was found for the 48 students participating in the study, we could compare their results to the OPT results. Figure 2 shows the graph representation of this comparison in percentages. 


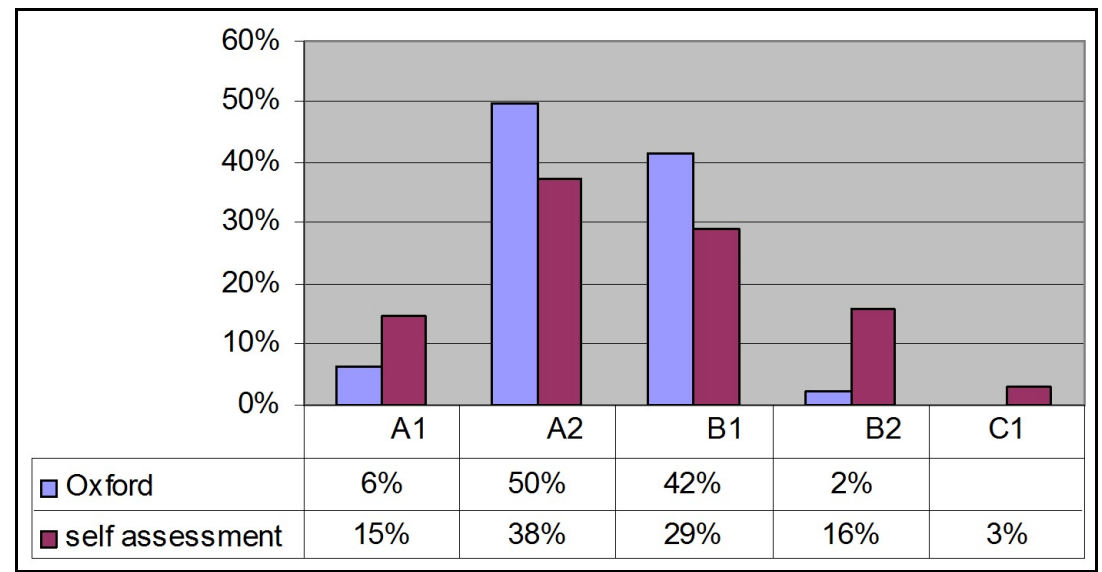

Figure 2. Comparison of Oxford Placement Test and self-assessment results.

At a first glance, we can see that the great majority of students fall under the A2 and B1 categories, in agreement with Oxford Placement Test results; whereas both A1 and B2 selfassessment results are somewhat higher than Oxford results. Only one student (2\%) scores himself at $\mathrm{C} 1$ level. So our next question was whether these results are statistically significant at a confidence level $\mathrm{p}<=.05$.

The non-parametric Wilcoxon Matched-Pairs Signed Ranks Test was used to determine the magnitude of difference between the test scores and the self-assessment, as well as their level of significance. The results are presented in table 2. In the first comparison (Oxford Placement Test results and calculated self-assessment), there were 10 cases where the students self assessed at a lower level (under-raters) and 16 students self assessed at a higher level (over-raters), with 22 students matching the two scores. In this comparison, $Z=-1.069$ and two tailed $\mathrm{P}=.285$, at a level of significance $\mathrm{p}<=.05$. This means that we cannot reject the null hypothesis that the two sets of scores from OPT and self-assessment are significantly different, and, therefore, we may accept a similarity in both external test scores and selfassessment. These results confirm our hypothesis at a confidence level of $5 \%(\mathrm{p}<=.05)$ that when students are given clear concrete criteria they are able to assess their language competence level.

\begin{tabular}{|l|l|l|l|}
\hline Wilcoxon & Self-rating & $\mathbf{N}^{\mathbf{0}}$ of cases & mean rank \\
\hline \multirow{3}{*}{$\begin{array}{l}\text { Oxford Placement Test and } \\
\text { Self-assessment }\end{array}$} & under-raters & 10 & 1375 \\
\cline { 2 - 4 } & ver-raters & 16 & 1334 \\
\cline { 2 - 4 } & match & 22 & \\
\hline \multirow{2}{*}{ DIALANG and } & under-raters & 3 & 1650 \\
\cline { 2 - 4 } & over-raters & 33 & 1868 \\
\cline { 2 - 4 } & match & 12 & \\
\hline
\end{tabular}

Table 2. Results of Wilcoxon.

With these findings, we may then conclude that students seem to be quite apt at selfassessment, at least in the skills of reading and writing, when they use clearly defined 
language learning outcome checklists, presented as 'can do statements' (see appendix), and the results of the Oxford placement exam as an external reference.

\subsection{Listening comprehension}

In the second comparison, DIALANG scores and DIALANG self-assessment scores, the results are quite different. Only three students self assessed at a lower level than the DIALANG level received. A remarkable 33 students self assessed higher than the assigned DIALANG level, 3 self assessed lower, and only 12 students had both scores matching. In this case, $\mathrm{Z}=-4.585$ and the two tailed $\mathrm{P}=.000$ at a significance level of $(\mathrm{p}<=.05)$. Therefore, we have to reject the null hypothesis that there is no significant difference between the two sets of scores, in this study. This means that, as the DIALANG test and self-assessment results are significantly different, we cannot accept these self-assessment results as reliable.

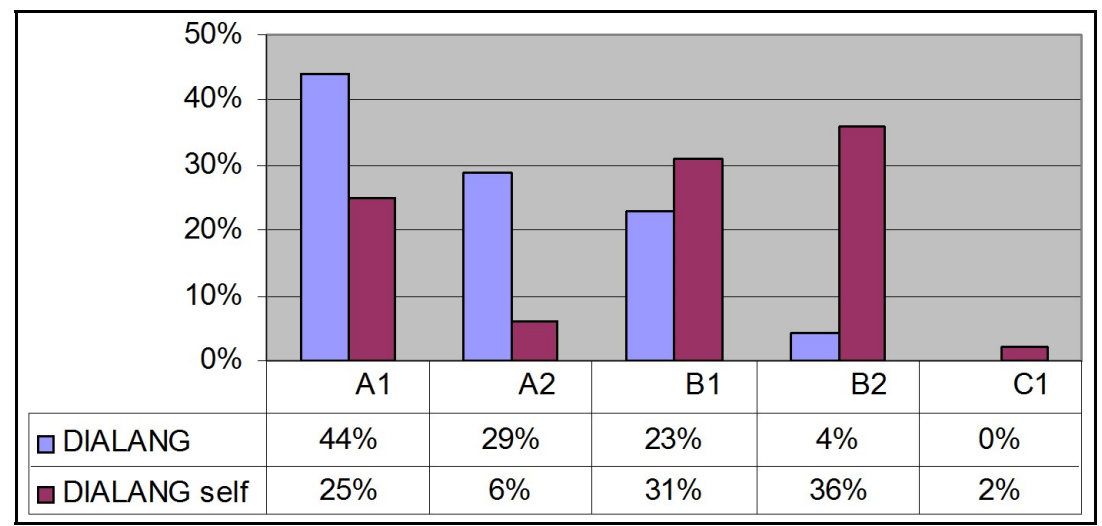

Figure 3. Comparison of DIALANG and students DIALANG self-assessment.

Figure 3 shows the comparison of DIALANG test results and students' DIALANG selfassessment scores in percentages. It is surprising that $41 \%$ of the students were placed at the A1 level, but only 16\% placed themselves at that level; and again, $22 \%$ were placed at the A2 and only $6 \%$ self assessed at that level, and so on. While concluding that, from these results, the students' ability to assess their listening comprehension competence level was not satisfactory, we need further studies before we reach any reliable conclusion. These data show a notable disparity, which requires further analysis, both of the instrument (DIALANG test) used and of the test conditions.

\section{Concluding remarks}

This study was designed to enhance our understanding of engineering students' capacity and reliability to assess their performance of the language tasks necessary to achieve a desired outcome previously selected for the course. Our aim has been to observe and describe 
students' performance in self-assessment, by studying the relationship between results of external placement and diagnostic tests and their self-assessment practices. As this study developed, it became clear that understanding learning outcomes was the first step in students' involvement and effort to achieve a desired outcome. Self-assessment is essential to learning because students can only achieve a learning outcome if they have identified it as a learning goal and are able to assess what they need to do to reach it. By focusing on the process aspect of reflective language learning, we teachers can help students to identify their learning goals, to monitor their learning processes and assess the outcomes. By involving this group of first year mining engineering students in their learning process, we have observed evidence of students' success in self-assessment, when we compared their OPT results to their learning outcomes' checklists. This evidence has been shown by using the Wilcoxon non parametric test, in relation to reading and writing skills. However, in relation to the listening skill, it has given negative results, which do not support the students' validity of their self-assessment level; both instrument and test conditions should be revised.

Therefore, we may conclude that the knowledge of expected language learning outcomes at the beginning of the course is one fundamental factor for self-assessment and that the introduction of learning outcomes and competence descriptors into engineering language courses can promote change towards student self-assessment practice. We also need further studies to support our conclusions in favour of reliable self-assessment practices.

\section{Notes}

1. The research group DISCYT, funded by the Comunidad de Madrid and Universidad Politécnica de Madrid, is made up of technical English teaching staff and researchers from the Architecture, Civil Engineering, Mining Engineering, Agricultural engineering, and Aeronautical Engineering degree programmes.

\section{References:}

Alderson, J. Charles (2005): Diagnosing Foreign Language Proficiency. New York: Continuum.

Bary, Raphaël and Michael Rees (2006): "Is (self-directed) learning the key skill for tomorrow's engineers?". European Journal of Engineering Education 31 (1), 73-81.

Black, Paul and Dylan Wiliam (2006): "Assessment for learning in the classroom”. In Gardner, John, ed., Assessment and Learning. London: Sage, 9-25.

Birenbaum, Menucha (1996): “Assessment 2000: Towards a pluralistic approach to assessment”. In M. Birenbaum and F. J. Dochy, eds., Alternatives in assessment of achievements, learning processes, and prior knowledge. Dordrecht, Netherlands: Kluver Academic, 3-29.

Boixareu, Mercedes, Nicole Dulin, and Carmen De Santiago (2000): Autoaprendizaje de lenguas extranjeras. Madrid: UNED.

Brunner, Jerome S. (1996): The Culture of Education. Cambridge, MA: Harvard University Press.

Council of Europe (2001): Common European Framework of Reference for Languages: Learning, teaching, assessment. Strasbourg: Cambridge University Press.

Council of Europe (2009): ETCS Users' Guide. Brussels 
[www.bologna.msmt.cz/files/ECTSUsersGuide.pdf].

Durán, Pilar, Georgina Cuadrado, Joana Pierce, Ana M Roldán, $\mathrm{M}^{\mathrm{a}}$ del Mar Robisco, Joaquín Santiago, and Paloma Úbeda (2009): Portfolio Europeo de las Lenguas Académico y Profesional. ACPEL Portfolio y Banco de Descriptores de Destrezas Comunicativas Profesional y Académico. Madrid: Ediciones Endimión. [Edición bilingüe español/ inglés. Modelo acreditado por el Consejo de Europa No 98.2009].

Durán, Pilar and Georgina Cuadrado (2007): "Developing language descriptors to match the writing competence of engineering students". In Bocanegra, Ana $\mathrm{M}^{\mathrm{a}}$, Lario, $\mathrm{M}^{\mathrm{a}}$ Carmen and López, Elena, eds., English for Specific Purposes: Studies for Classroom Development and Implementation. Cádiz: Universidad de Cádiz, 105-124.

Durán, Pilar and Pierce, Joana (2007a): “An EAP literacy portfolio for tertiary education students: Academic and professional discourse development within the European framework of reference for languages". In A. Curado, P. Edwards and M. Rico, eds., Approaches to Specialised Discourse in Higher Education and Professional Contexts. Newcastle, UK: Cambridge Scholars Publishing, 182-197.

Durán, Pilar and Pierce, Joana (2007b): "ELP implementation concerns from a pedagogic perspective in an EST context". In Teaching and Learning LSP: Blurring Boundaries, VI International Conference of the European Association of Languages for Specific Purposes (AELFE), ISCAL Lisboa (Portugal), 56-62.Foster Vosicki, Birgit (2002): European Language Portfolio for Higher Education. European Language Council: Bern.

Gardner, John, ed., (2006): Assessment and Learning. London: Sage.

Huba, Mary E. and Jann E. Freed (2000): Learner-Centered Assessment on College Campuses: Shifting the Focus from Teaching to Learning. Bilbao: Allyn and Bacon.

Inbar-Lourie, Ofra (2008): "Constructing a language assessment knowledge base: A focus on language assessment courses". Language Testing 25(3): 385-402.

Johns, Ann M. (1997): Text, Role, and Context. Developing Academic Literacies. New York: Cambridge University Press.

Kavaliauskiené, Galina, Ligija Kaminskiené, and Lilija Anusiené (2007): "Reflective practice: assessment of assignments in English for Specific Purposes". IBÉRICA. Journal of the European Association of Languages for Specific Purposes 14, 149-166.

Kollias, Annette and Katherina Kikis (2005): Pedagogic Innovations with the use of ICTs: From wider visions and policy reforms to school culture, Barcelona: Universitat de Barcelona

Lenz, Peter and Gunter Schneider (2004): A bank of descriptors for self-assessment in European Language Portfolios. Strasbourg: Council of Europe. [www.coe.int/portfolio].

Light, Greg and Roy Cox (2001): Learning and Teaching in Higher Education: The Reflective Professional. London: Paul Chapman.

Little, David (2005): "The Common European Framework and the European Language Portfolio: involving learners and their judgements in the assessment process". Language Testing 22.3, 321-336.

. (2007): "Language Learner Autonomy: Some Fundamental Considerations Revisited". Innovation in Language Learning and Teaching 1, 1, 14-29.

Little, David and Radka Perclová (accessed 2005) The European Language Portfolio: A Guide for teachers and teacher-trainers.

[www.coe.int/T/DG4/portfolio/documents/ELPguide_teachertrainers.pdf].

Meichenbaum, Donald and Biemiller, Andrew (1998): Nurturing Independent Learners. Massachusettes: Brookline Books. 
Pierce, Joana and Paloma Úbeda (2006): "The European Language Portfolio: Review of the Implementation in Higher Education”. In R. Mairal, ed., Aprendizaje de lengua, uso del lenguaje y modelación cognitiva, XXIV Congreso Internacional AESLA. Madrid: UNED, 991-997.

Pierce, Joana and Pilar Durán (2008): Language Communication Competences in Engineering Education Revisited. Revista de Lenguas y Lingüistica Aplicada 3, 59-72.

Pierce, Joana and Maria del Mar Robisco (2010): "Evaluation of oral production learning outcomes for higher education in Spain". Assessment and Evaluation in Higher Education 35, (6) 745 - 758.

Robinson, Pauline (2002): "Learning conditions, aptitude complexes and SLA: A framework for research and pedagogy". In P. Robinson, ed., Individual differences and instructed language learning. Amsterdam: Benjamins, 113-134.

Schneider, Gunter and Peter Lenz, (2000): European Language Portfolio: Guide for Developers. Fribourgh, CH: University of Fribourgh.

Sfard, Ana (1998): "On two metaphors for learning and the dangers of choosing just one". Educational Researcher 27, 4-13.

Skehan, Peter (1998): A Cognitive Approach to Language Learning. Oxford: OUP.

Van Lier, Leo (2007): “Action-based Teaching, Autonomy and Identity”. Innovation in Language teaching 1 (1) 46-65.

Yang, Nae-Dong (2003): "Integrating portfolios into learning strategy-based instruction for EFL college students". International Review of Applied Linguistics in Language Teaching, 41/4, 293-318. 
Appendix 1: Sample of the learning outcomes and course objectives used for the study by skills and

CEFRL levels

\begin{tabular}{|c|c|c|}
\hline & RECEPTION: SPOKEN & 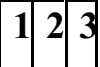 \\
\hline $\mathrm{A} 2$ & $\begin{array}{l}\text { I can understand the essential information in short recorded passages relating to familiar } \\
\text { topics if they are spoken slowly and clearly. }\end{array}$ & \\
\hline B1 & $\begin{array}{l}\text { I can understand the information content of the majority of recorded or broadcast audio } \\
\text { material on topics of scientific or professional interest delivered in clear standard speech. }\end{array}$ & \\
\hline \multirow[t]{2}{*}{ B2 } & $\begin{array}{l}\text { I can understand the main ideas of complex speech on both concrete and abstract topics, } \\
\text { including technical discussions in my field of specialisation. }\end{array}$ & \\
\hline & READING COMPREHENSION & 123 \\
\hline B1 & $\begin{array}{l}\text { I can understand the most relevant information in informative texts related to my interests and } \\
\text { academic field, provided I can reread more difficult sections. }\end{array}$ & \\
\hline B2 & $\begin{array}{l}\text { I can understand in detail long and complex texts within my areas of interest, in which writers } \\
\text { express opinions, appreciating different styles and purpose. }\end{array}$ & \\
\hline $\mathrm{C} 1$ & $\begin{array}{l}\text { I can uderstand detailed and complex reports and articles within my field, with the occasional } \\
\text { use of a dictionary. }\end{array}$ & \\
\hline & Reading Strategies & $1 \quad 23$ \\
\hline B1 & $\begin{array}{l}\text { I can derive the meaning of unknown words from the context on topics related to my field of } \\
\text { interest. }\end{array}$ & \\
\hline B2 & $\begin{array}{l}\text { I can look through a specialised text within my field (e.g. reports and articles) and predict its } \\
\text { content from the title, headings, subheadings and figures. }\end{array}$ & \\
\hline \multirow[t]{2}{*}{$\mathrm{C} 1$} & $\begin{array}{l}\text { I can use a variety of strategies to understand a complex text, including word-building, } \\
\text { grammatical, and other contextual clues. }\end{array}$ & \\
\hline & $\begin{array}{l}\text { OVERALL WRITTEN PRODUCTION } \\
\end{array}$ & 12 | 3 \\
\hline B1 & $\begin{array}{l}\text { I can write simple connected texts on familiar topics marking relationship between ideas, with } \\
\text { reasonable grammatical correctness. }\end{array}$ & \\
\hline \multirow[t]{2}{*}{ B2 } & $\begin{array}{l}\text { I can write clear and detailed texts such as short essays, reports and texts of presentations on } \\
\text { topics related to my fields of interest, varying my vocabulary and style according to the kind } \\
\text { of text. }\end{array}$ & \\
\hline & Reports & 123 \\
\hline A2 & I can write brief and simple reports to communicate technical factual information. & \\
\hline B1 & $\begin{array}{l}\text { I can write a short and clear lab report on an experiment related to my academic subjects, } \\
\text { using technical language with reasonable accuracy. }\end{array}$ & \\
\hline \multirow[t]{2}{*}{ B2 } & $\begin{array}{l}\text { I can write technical reports which develop an argument, giving reasons to support or negate } \\
\text { point of view, using appropriate language with occasional errors. }\end{array}$ & \\
\hline & Cover letter & 123 \\
\hline A2 & $\begin{array}{l}\text { I can write a short simple cover letter using the conventional format (date, address, salutation } \\
\text { and closing remarks), following standard models. }\end{array}$ & \\
\hline B1 & $\begin{array}{l}\text { I can write a brief statement of introduction explaining my motivations, provide clear and } \\
\text { correct sentences making reference to my enclosed CV and express politely my availability } \\
\text { for an interview, in my cover letter. }\end{array}$ & \\
\hline
\end{tabular}


B2 II can write a clear, correct and properly sequenced cover letter showing evidence of my motivation, academic preparation and professional experience, making reference to my $\mathrm{CV}$.

Writing Strategies

A2 I can make an outline of what is to be said, considering the type of writing and its purpose, when planning the piece of writing.

B1 I can check my piece of writing for clarity and cohesion, reviewing punctuation, the use of linking words and text organisation.

B2 I can check the use of precise terminology and avoid word repetition looking for synonyms, when reviewing my papers. 